\title{
HEALTH ACTIVITIES OF STATE COUNCILS OF DEFENSE
}

\author{
By Arthur W. Macmahon, \\ Washington, D. C.
}

The maintenance of civilian health in war time, when people are subjected to unusual strains and when the ranks of practitioners and nurses and the staffs of hospitals and departments of health are depleted by the needs of the military establishment, is a problem of national defense which increases daily in importance. The connection of this problem with war relief work is real but in general indirect. For that reason anything more than an indication of the nature of the activities of state councils in the field of health would be out of place in this volume.

In the first place, a practical distinction must be drawn between the work of mobilizing medical resources for direct war service and health work, involving contact with the general public. Not only is the former work further removed from war relief in the strict sense, but it has on the whole been accomplished through machinery other than the state councils of defense. Despite its importance, it is, therefore, treated only incidentally in this article. The primary agents concerned in medical mobilization have been the Medical Section of the Council of National Defense, created on December 12, 1916, as its first subordinate body, and the General Medical Board, constituted on February 1, 1917, around the medical member of the Advisory Commission. The first of these bodies acts as the executive arm of the latter, which is deliberative; together they may be regarded as the Medical Committee of the Council of National Defense.

Even before our entrance into the war, the Medical Section was authorized to create a system of state and county committees, which it did by appointment from among strictly professional circles, for the most part taking over the personnel of the subsidiaries of the pre-existing Committee of American Physicians for Medical Preparedness. These state and county committees have been subject to the instructions of the Medical Section, and have been in constant direct correspondence with it; they have thus constituted an avenue by which the National Government has communicated its policies and requirements with regard to war-time medical 
problems of essentially national character, to the members of the medical profession. Many of the phases of medical mobilization, such as the standardization of surgical supplies to offset the cessation of German importations, have been capable of direct adjustment from Washington without the intermediation of these local committees. Other matters, such as the recruitment of doctors for the Medical Reserve Corps (which has probably been the most important phase of medical mobilization) or the constitution of medical advisory boards in connection with the Selective Service Law, have involved action by the state and county committees.

The connection of the state councils of defense with the work of mobilizing medical resources for direct war service, has thus depended primarily upon the relation existing in each state between the committee of the Medical Section and the state council of defense. About three-fourths of the state councils have constituted committees having specifically to do with health matters. The personnel of a number of these committees is identical with that of the committees of the Medical Section in these states. In nearly all of the other states, the two committees have certain officers or at least members in common. In the cases where especially favorable relations have been worked out, the state council has given financial and other support to the state committee of the Medical Section, without breaking its direct communication and responsibility in medical matters essentially national in character, and has thus aided in the work of medical mobilization for war service. As the months pass, the meaning of medical mobilization becomes broader. At first, while the tremendous initial needs of our new army and navy were being filled and lines laid to meet the continuing requirements, the imperative objectives of medical mobilization were of course military; it was work by doctors with doctors to meet military necessities, and the result has been as splendid an out-pouring of personal sacrifice as the world has yet seen made by any professional group. From now on, increasing attention can be given to a problem which has, of course, been recognized from the first-the adjustment of the remaining medical resources to the needs of the civilian population. This is not the place to state how the problem will be worked out. Undoubtedly the Volunteer Medical Service Corps (the official organization of doctors not in military service, who pledge themselves for war service at home) will be an important 
instrument in securing this adjustment. The delicate task of building up the personnel of the Volunteer Medical Service Corps, is being conducted primarily through the machinery of the Medical Section. The work of the corps will undoubtedly bring it in contact with war relief organizations. The state and local councils of defense, as coördinating bodies, with facilities for reaching the general public, will be necessarily drawn into this work.

In turning to the health activities of state councils, as distinguished from the more strictly medical lines of work, the relation of the councils to existing health agencies within the states should first be indicated. In this, as in other matters, the state councils work with and largely through existing organizations. Naturally, relations with state boards of health are particularly close, and in one-half of the cases in which the council has a committee specifically charged with health matters, the state health officer is on the committee, usually as chairman. The Council of National Defense, at the instance of the U. S. Public Health Service, has used the councils of defense to further centralize reporting of morbidity data, - in one case, reporting at regular intervals from cities of a population of over 10,000 to the Public Health Service, in the other emergency notification of camp medical authorities by local officers. In this work, as in all its suggestions on health matters, the National Council has sought to avoid cutting across and breaking the hierarchy of health officials which has been growing up so wholesomely in the United States.

The State Councils also work with important semi-private health organizations, where these are already in the field. Thus the Oregon State Council, having $\$ 10,000$ of its 1917 funds given it expressly to be spent in improving moral conditions around camps, added a representative of the Oregon Social Hygiene Association to its membership, and helped to maintain other representatives of the association in the field. The Illinois Council, in taking up the tuberculosis problem recently, with reference especially to men rejected in the draft or discharged from service because of tuberculosis, has worked with a pre-existing body known as the "Coöperating Committee on Tuberculosis War Problem," and has had the local representatives of that body made chairman of county council committees on the subject. Or, to cite another example, the Texas State Council has, in its material on general health, always included 
the slogan, "Join the Texas Public Health Association," or when dealing with venereal diseases, "Join the Texas Social Hygiene Association."

In what ways can councils of defense help the normal health agencies? Generalizing, we may say: since they exist to meet war emergencies, the councils can put the war appeal back of health work; since they parallel governmental organization within the state, and at the same time have a non-routine, non-political point of view, they are in a strategic position to influence local governments to take such steps as war conditions require; since they usually have emergency funds not minutely tied up by legislation, they can finance measures which regular departments cannot meet; since one of their primary functions is to be a mediating, coördinating influence, they can bring health agencies together; finally, they have unusual channels for reaching the general public.

Regarding the health activities themselves, although interesting work has already been done, such activities lie rather in the future than in the past. During the first phase of our participation in the war, when, for all that European experience was before us, we did not fully realize how far-reaching are the reactions of war on civilian life, state councils, in so far as they initiated health activities at all, naturally tended to confine these to special groups or special diseases having an obvious and immediate military connection. During 1917, for example, the Connecticut State Council arranged for the free medical treatment of men barred from enlistment, because of slight physical defects or rejected in the draft for similar reasons. It also coöperated with an organization of dentists in giving free dental treatment to recruits. The South Carolina State Council worked out with the Anti-tuberculosis Association, the State Board of Health, and other interested agencies, a plan by which all men rejected by draft boards because of tuberculosis, were followed up and treated. Other state councils have carried out or at least considered plans for the treatment of those wishing to enlist, and for the reclamation of physical rejects. Such work would have gone much further if there had been national encouragement. In view of the heavy demands which were being made concurrently upon the medical profession and upon hospitals, however, it has been impracticable up to the present time to suggest that such reclamation be attempted on a widespread scale. 
Aside from the prosecution of particular problems, such as venereal disease control, there has been a growing interest on the part of state councils of defense in the maintenance of civilian health generally. The recent development of this interest has been the result, partly of a clearer realization that, in the words of the President, "This war is one of nations--not of armies," partly of the depletion of the normal facilities by which health is maintained, and partly of the establishment of the community councils of defense, which have made available unique machinery for carrying a message to the masses and which, from the beginning, have had health as one of the objectives set before them.

It is only fair that the first example of this interest on the part of state councils should be one of many months standing. The Committee on Sanitation and Medicine of the Texas State Council of Defense, has been working on a plan which has included the following elements. Since November, 1917, the committee has drawn up a weekly "health-hint," which it has sent to 350 daily and weekly newspapers in the state, to be printed during the week of release in uniform boxed style under the heading, "Help Win the War by Preventing Unnecessary Sickness." Some of these "health-hints" have given specific information regarding the avoidance and cure of specific diseases; others have urged citizens to take stock of their present local health machinery and, where necessary, to agitate for more ample machinery. The committee made a survey of health conditions in Orange, where ship-building has suddenly doubled the population, and published recommendations which got local citizens agencies working and has resulted, among other improvements, in provision for a full-time health officer. The Texas committee stands ready to advise other communities directly regarding specific problems. In general, however, its task is to encourage every community to constitute a "Citizens' Committee on Public Health," consisting of representatives of all local organizations (eleven kinds being suggested by the state council), to hold weekly meetings at which health officials shall be introduced to the public they are trying to serve, to make rapid practical surveys of local health organization and to work for better machinery, if necessary, and to spread simple information regarding personal hygiene. Other examples have been the circulation of Pamphlet No. 3 of the Department of Civic Relief of the Pennsylvania State Council of Defense, 
entitled "Community Organization in War Time-Health" (which is discussed in another article), and the instigation by the Woman's Division and State Council of a survey of the health administration of the State of Delaware, through the New York Bureau of Municipal Research.

Recently, there has been evidence that state councils of defense, although at the time of writing (July) no formal recommendation from the national government has yet been sent them on the subject, are anxious to carry public health activities even further. The most thorough plan for a state-wide health campaign which yet has been worked out is that of the South Carolina State Council of Defense. The state council has declared the spread of information about the avoidance of disease to be strictly a war emergency measure, and set aside $\$ 5,000$ for the conduct of an intensive state-wide camprign during August, 1918. The objectives, which were worked out at a conference of health leaders called by the state council, are: child welfare, venereal diseases, insect-borne diseases - typhoid, dysentery and malaria, and tuberculosis. Chief attention will be given to the rural districts. Although the primary purpose is to tell the individuals how to keep well and to give the war as motive to act, it is expected that on the social side the campaign will arouse interest in full-time county health officers and other improvements. A two-days institute has been called to meet just before the opening of the intensive campaign, for the instruction of a corps of speakers who will then scatter in groups through the states. In addition to a speakers' handbook, leaflets giving health rules in simple language are being prepared, and every available means of publicity will be utilized by the council, which, by reason of its central position in the war work of the state, can enlist the services of all agencies in the health drive.

Doubtless, even if they were left entirely to their own initiative, many state councils would undertake somewhat similar health campaigns. It is probable that the Council of National Defense, however, which has been waiting until the time was ripe and particularly until the community council system was under way, will shortly recommend that a public health campaign be launched in each state, to be pressed with especial vigor at first and to be carried on as a permanent activity by community councils of defense for the duration of the war. The recommendations of the Council 
of National Defense to the state councils, would have to be worked out in further detail in each state to fit its peculiar conditions, which would probably involve a conference or "war congress" of the leaders in sanitation and medicine in each state, including especially the state department of health and the state committee of the Medical Section. Further, it is probable that in these recommendations the National Council will call for a campaign which will involve: first, direct and indirect pressure to secure better health facilities in localities where these are notably deficient; second, the federation in each community, through a "local health congress" under the community council, of all agencies, public and private, which touch the health and welfare of the people, in order to arrange for the maximum utilization of their facilities and to popularize these facilities; and, finally, the education of individual citizens in the reason why it is patriotic to keep well and how to do so. In so far as the resulting activities of state and local councils of defense prevent disease, they would have a vital, if indirect, bearing on all relief work. In so far as community councils of defense, in carrying out the public health program, bring together all agencies working with the people in each neighborhood, where at present they waste effort like a badly meshed grinder, they would point the way for one of the most important developments in relief work.

\section{HEALTH AND RECREATION}

By Mrs. Philip North Moore,

Chairman, Department of Health and Recreation, Woman's Committee, Council of National Defense.

Another department of the Woman's Committee pertaining to war conditions of the camps and surrounding communities, is that of Safe-guarding Moral and Spiritual Forces, the health and recreation of the soldiers. The Woman's Committee recognized the need of protective work in and around the camps before the War Commission on Training Camp Activities was appointed, writing to President Wilson, urging him to use his authority in regard to the sale of liquor and moral protection from the resorts of the towns,- 